\title{
IS THE TRUTH DOWN THERE?: Cultural Heritage Conflict AND the Politics of ARCHAEOLOGICAL AUTHORITY
}

\author{
IAN BARBER
}

Public History ReVIEW, VOL 13, 2006, PP143-154

$\mathrm{G}$ enerally it is acknowledged that conflict is axiomatic in any contemporary system of heritage (or cultural) resource management. ${ }^{1}$ Tunbridge and Ashworth ${ }^{2}$ argue that dissonance ('a discordance or a lack of agreement and consistency') is 'intrinsic' to heritage, since 'selection is inevitable' and 'any creation of heritage from the past disinherits someone [else] completely or partially, actively or potentially'. In this process there may be conflict between stakeholders who feel alienated from the physical reference points of their own past, and those decision-makers who would modify or appropriate that past.

In overview, the selection pressures that are at the core of cultural heritage conflicts are complex and wide-ranging. Disagreement spans differences over the treatment and care of sites through to the targeted destruction of cultural property and associated customary communities. ${ }^{3}$ Affected communities may contest decisions that seem to dismiss their own heritage sites and associated narratives and practices. At the extreme end of the scale, these differences may lead to sectarian violence and the destruction of cultural property. Conflict can also occur between cultural heritage practitioners themselves over how, and even whether, to research the contested past. ${ }^{4}$

The appeal of the material archaeological record is often enhanced where the past is referenced in postcolonial or nationalist conflicts. In these disputes, archaeologists may be found as expert witnesses in legal proceedings (for example, Sutton's article in this volume) or as public advocates for or against communities with customary or other cultural heritage associations. ${ }^{5}$ Newly discovered archaeological features and artifacts may be given considerable if tendentious weight or be subject to critical scrutiny and dismissal. This is powerfully illustrated in the political uses of the archaeological record that have characterized debate over the 1992 destruction of the Babri mosque at Ayodhya in the northern Indian state of Uttar Pradesh. ${ }^{6}$ Conflict may even be sustained where sectarian groups agree superficially about protecting the same archaeological heritage. For example, Catholic and Protestant communities of the 
late twentieth century have supported the preservation of prehistoric Eiman Macha or Navan Fort, but with reference to very different interpretations of the meaning of the place for the traditional heroic past, and present. ${ }^{7}$ And a broad consensus about the importance of Stonehenge cannot mask other differences between planners, archaeologists and nationalist, environmental and New Age interest groups over the use and celebration of the larger site area. ${ }^{8}$ However, while archaeological values may be debated vigorously in these situations, the basic methods and assumptions behind the archaeological evidence are usually accepted as legally admissible and self-evident in judicial hearings (although not necessarily by the affected communities themselves).

This article evaluates the authority of archaeology where cultural heritage interpretations are in public conflict. It asks two questions. Firstly, how conflicted and (therefore) political are the theoretical foundations of archaeology themselves in the project of documenting, and potentially resolving differences over, the material cultural past? And secondly, has the authority of archaeology proved uniquely conclusive where matters of identity and belonging are in conflict in the present?

\section{POLITICS, CONFLICT AND THE FOUNDATIONS OF ARCHAEOLOGICAL THEORY}

By the beginning of the twentieth century, archaeology had emerged as a systematic field of anthropological study in the culture history mode. This approach is characterized by the formal classification of artifacts and (less consistently) site types that define chronological sequences of cultural identity and geographical relationships. This early archaeological emphasis on regional sequences represented an intellectual shift away from (if not a reaction against) the universal and unilinear evolutionary scenarios of nineteenth century anthropology, associated with such famous names as E. B. Tylor, Lewis Morgan and John Lubbock. ${ }^{9}$

Culture history archaeology did not develop in a sociopolitical vacuum. Nineteenth century unilinear cultural evolution had been applied to explain and in some cases justify European progress and superiority, especially over colonized peoples. ${ }^{10}$ Culture history archaeology by contrast was concerned less with universal explanation than with the material culture description of geographically discrete and dispersed archaeological cultures. In this view, change was affected primarily by the diffusion of artifacts and the migration of peoples, or it was assumed rather than explained. It has been argued that culture history was stimulated in part by the emergence of new polities and identities from the collapse of the empires and monarchies of Old Europe. ${ }^{11}$ In some cases these earlier twentieth century culture historians or their political patrons 'attempted to trace the development and origins of extant ethnic groups', where their work could be used 'to support nationalist causes'. ${ }^{12}$ The most notorious example of this support is Nazi sponsored archaeology, which was intended to demonstrate the Germanic lineage of a dominant European warrior Aryan civilization. ${ }^{13}$ This racial interpretation referenced German scholar Gustaf Kossinna (1858-1931), 
who had argued patriotically for the Germanic origins and dispersion of creative Indo-European peoples based on the archaeological, linguistic and ethnic identification of prehistoric European cultures. ${ }^{14}$

The archaeology of the Soviet Union between the 1930s and 1950s incorporated a reactionary mirror image of Nazi archaeology. Soviet archaeologists were encouraged to identify the Slavic influence of the Great Russian people at the forefront of developments in European prehistory, at the expense of the role of Germanic peoples. ${ }^{15}$ The Cambridge Marxist archaeologist V. Gordon Childe (1893-1957), perhaps the most influential European archaeologist of this time, developed a more systematic approach to classification and consequent cultural identification. Childe carefully described geographically discrete assemblages of artifacts and (where possible) associated economic, political and religious expressions so as to define a mosaic of archaeological cultures distributed over time and space. These prehistoric cultures were interpreted as mutable chronological and social, rather than racial, entities. ${ }^{16}$ Even then, Childe's early interpretations were also not entirely free of racial speculations. However, these were repudiated in his later works that effectively challenged the essentialist, ethnic culture history assumptions of Kossinna's theory, and later European fascist practice. ${ }^{17}$

The period of archaeology's dominance by culture history's descriptive 'classificatory-historical' approach (as described by American archaeologists Willey and Sabloff $)^{18}$ was dramatically challenged from the late 1950 s by a 'new' archaeology. Now known generally as processualism, the new archaeology was concerned with cultural process, ecological context and explanation. It built on significant post-war scientific advances (especially radiocarbon dating and chemical and molecular identification and sourcing), while it promoted explicit research design (especially hypothesis testing), and the search for universal laws of human behaviour. The ability to frame and scientifically assess the validity of theories of change is fundamental to processual archaeology. As archaeologist Lewis Binford, the most prominent theorist and advocate of this school, has argued: 'without some methodology for evaluating ideas, we are in the position of having a free hand to generate lots of stories about the past, but not having any means of knowing whether these stories are accurate'. ${ }^{19}$

With a disinterest in particular historical traditions and an emphasis on applied technologies and universal law-like generalizations, the roots of processual archaeology are clearly identified in the postwar period of optimism and conformity that referenced applied science, universal humanism and the economic and political hegemony of the United States. ${ }^{20}$ As Trigger has argued, 'the New Archaeology followed the lead of the generalizing social sciences... by claiming to be able to produce objective, ethically neutral generalizations that were useful for the management of modern societies'. ${ }^{21}$ The methods of processual archaeology were comfortably integrated into the regulatory requirements for archaeology associated with surging international urban and industrial development. Archaeological heritage and other environmental effects 
of development were now defined, and 'mitigated', by conforming and sometimes collaborative scientific approaches (even if the strict intellectual and sampling requirements of research design were often not met in salvage archaeology). ${ }^{22}$

From the 1970s several archaeologists challenged the search for universal laws and authoritative narratives that had come to dominate the discipline. Their ideas have been identified within the postprocessual or interpretive archaeology school. This approach draws variously on debates generated by other 'post-' movements, especially poststructuralism and postcolonialism. Interpretive archaeology assumes that archaeologists work from a particular and contingent understanding of the world with the remains of a fragmentary past that can never be objectively recovered or known. In this approach, the past may be no more predictable than the future. ${ }^{23}$ Some interpretive archaeologists are motivated by a concern that processual archaeology does not account for the agency of indigenous communities in the past, and the present. To varying degrees, these scholars allow that archaeological narratives and values may have no more authority to account for the past than the views of descendant or other customary communities. ${ }^{24}$ In its challenge to conformist establishment narratives and scientific authority, interpretive archaeology has provided a theoretical home to emerging postcolonial, minority and gender archaeologies. ${ }^{25}$

On the face of it, then, contemporary archaeology is caught between the theoretical poles of essentialist conformity and relativism. On closer inspection these extremes frequently bleed into a range of theoretical grey areas and political positions. Most archaeologists today continue to objectify material remains and follow standard analytical methods in their research (including, where appropriate, culture history approaches), while acknowledging increasingly that the generation of archaeological knowledge is not a neutral exercise. However, if texts such as Bruce Trigger's History of Archaeological Thought have done much to promote a disciplinary understanding of the role of ideology in archaeology, there are still important differences in some of the assumptions behind the superficially similar products of professional archaeology today. This is not just a matter of theoretical dissonance between archaeological researchers. During the 1990s, the manipulation and destruction of history and archaeology by protagonist ethnicities and nations emerging from the collapse of the Soviet Union and Yugoslavia challenged archaeologists to reconsider the role of archaeological knowledge. The editors of a 1995 volume of essays on nationalist politics and archaeology observe that postprocessual relativism 'provides no guide for determining when one should encourage the conscious construction of national pride and when one should condemn it as excessively chauvinistic'. ${ }^{26}$ In his own essay in this volume, Bruce Trigger responds further that 'the discipline's "findings" have promoted bigotry, violence and destruction at least as often as they have promoted social justice'. He adds that extreme relativism does not lend itself 'to justify political programs in a reasoned fashion'. ${ }^{27}$

The relatively more relativist editors of a volume on the destruction and conservation of cultural property (including essays on the former Yugoslavia and 
Ayodhya) defend 'the right of all peoples to create a past for themselves'. These editors pronounce against arguments for proclaiming the singular truth of history (even where Holocaust-denial is the issue), while asserting that their approach does 'not preclude the critical evaluation of the use... of archaeological evidence, and of the political values embedded in accounts of the past'. ${ }^{28}$ However, with respect to 'the less clear-cut arena' of identity politics and archaeology, they suggest that 'it is open to question whether anyone is in a position to decide which viewpoints are too extreme to be included in dialogue'. ${ }^{29}$

From this review of ideas and literature, archaeology's potential role in heritage conflict resolution might seem to be seriously compromised by its own theoretical conflicts. The relevance of the discipline may be tested further in emerging nation-states, where official guardians of the sacred traditional past attempt either to suppress archaeology, or conversely, with their political allies, to use archaeological monuments 'to reinforce their own preeminence'. ${ }^{30}$ These points are now explored with reference to case studies in a variety of political situations where archaeology has been appealed to or deemed irrelevant (respectively).

\section{Conflict and the Selective Appeal to Archaeology}

The destruction of the Babri Masjid (mosque) at Ayodhya, briefly introduced above, is a salient example of the partisan appeal of archaeology in a context of sectarian conflict and violence. According to the Hindu epic Ramayana, Ayodhya was the birthplace and sacred capital of the deity king Lord Rama. Today Hindu nationalists identify this legendary capital with the present northern Indian town of Ayodhya where they believe that an ancient temple had once memorialized the exact site of Rama's birth. Since at least about the eighteenth century, various claims have circulated that Rama's Ayodhya temple had been razed and replaced by the Masjid which was constructed in AD 1528-9 while India was under the rule of the Islamic Mughal emperor Babur.

The first clash between Muslims and Hindus over the Ayodhya Masjid site occurred in the 1850s. Since Indian independence, Rama's legendary birthplace at Ayodhya has become an important place of pilgrimage and a critical symbol of Hindu nationalism. Following the installation (or to Hindu nationalists, the miraculous appearance) of images of Rama and other deities within the Masjid in 1949, the mosque was locked up under government orders. Calls to pull down the Masjid and replace it with a Hindu temple grew more insistent and strident through the 1980 s, leading to violent demonstrations and death. In the immediate aftermath of the December 1992 destruction of the mosque, communal violence ensued with the death of at least 1000 and perhaps as many as 2000 people. Since then India has seen a protracted inquiry into the mosque's destruction and periodic violence, while majority nationalists continue to press for the construction of a Hindu temple on the site. ${ }^{31}$

The involvement of archaeologists and other scholars in the conflict precedes the mosque's destruction. The archaeological debate has been 
vigorous and on occasion, marked by physical confrontation, as occurred at the third World Archaeological Congress meeting in New Delhi in 1994 where the local organizing committee had banned discussion (and therefore condemnation) of the mosque's destruction. As 'tempers ran high', the plenary session was unable to pass a resolution condemning 'fraudulent manipulation of evidence' and the destruction of historic structures in support of sectarian claims. A further WAC meeting was convened in 1998 in Croatia for the free discussion of Ayodhya and other issues of cultural conflict and site destruction. ${ }^{32}$

Two published papers from the 1998 conference present archaeological evidence respectively in favour of, and against, the existence of an ancient Ayodhya temple to Rama on the Masjid site (among others on the theme). Retired Director General B. B. Lal of the Archaeological Survey of India references the 1970s Ayodhya component of his 'Archaeology of the Ramayana sites' project. Lal describes an excavated trench about four metres south of the Masjid where a recorded sequence of occupation began with the 'Northern Black Polished Ware culture' (ca seventh century BC). ${ }^{33}$ From the records of this excavation Lal refers to a series of 'brick built bases' that had 'evidently' carried stone pillars from a structure predating the Masjid. It is Lal's further contention that fourteen non-Islamic black basalt pillars incorporated into the mosque had come from the destroyed Hindu temple. ${ }^{34}$

Lal also clarifies his own public contribution to the debate. It is conceded that the brick base evidence was not reported publicly until 1988, 'since around that time questions had begun to be asked about the discovery of these pillarbases'. ${ }^{35}$ However, Lal points out that his suggestion for further excavations in the area, 'including that under the mosque' (a recommendation opposed in the Indian press in 1991 by 'twenty eminent historians') had come with the recommendation that the Masjid structure not be harmed 'in any way'. Lal recites his 1991 challenge: 'Why should the contending parties shy away from further excavation, unless they are afraid of facing the truth?'. ${ }^{36}$

From the 1998 WAC conference Indian scholar Ram Sharma presents an alternative view. ${ }^{37}$ Sharma points out that the brick bases recorded by Lal were made of broken bricks from earlier structures, with no evidence of religious affiliation or any connection to the basalt pillars in the mosque. The recovery of glazed Islamic ware pottery above the floors of this earlier brick base structure and below the Masjid indicate that it had collapsed by the time of the mosque's construction. ${ }^{38}$ Sharma notes also that the decorative motifs of the fourteen nonstructural mosque pillars cannot be distinguished between Buddhist or Hindu traditions. 'By the tenth century there was so much fusion in the elements of art cultivated by different sects that the sectarian elements are, in practice, almost indistinguishable'. The pillar motifs that are most specific, however, appear to have an affinity with east India Buddhist art and architecture. Sharma also cites evidence that other historic religious structures, including mosques, had been constructed or decorated with materials brought from some distance. ${ }^{39}$ 
Sharma and Lal disagree further over the interpretation of architectural materials and a stone inscription that were reportedly recovered by Hindu activists after the Masjid had been destroyed. ${ }^{40}$ Lal suggests that these materials 'must have once constituted parts of the temple', just as other materials from destroyed temples have been incorporated into other Indian mosques. The stone inscription is said to refer to a 'beautiful temple of Vishnu-Hari' constructed at Ayodhya, which Lal observes, 'speaks for itself'. ${ }^{41}$ In response, Sharma raises concerns over the lack of stratigraphic control and contextual information for the recovered materials. On the stone inscription, he references epigraphic evidence that the text is seventeenth century, and claims that the name 'Vishnu-Hari... cannot stand for Rama'. Sharma observes further; 'Why and how this seventeenth-century stone inscription... was... concealed in the brick wall of a sixteenth century mosque will remain a mystery'. ${ }^{42}$

The archaeological debate has been renewed by an unprecedented court ordered archaeological investigation by the Archaeological Survey of India at Ayodhya, published as 'Ayodhya: 2002-03'. The report describes pillar bases of what appear to be the halls of a pre-Masjid structure and the circular brick structure of a shrine (ca seventh-tenth centuries AD). However, no distinctive images or epigraphs are associated with these remains. ${ }^{43} \mathrm{~A}$ reviewer observes that "for those who are trying to "fit" archaeological data with the requirements of "proving" or "disproving" the historicity of religious figures and of temples constructed in their honor, the report is not likely to be as "useful" as the current posturing around it suggests'. ${ }^{44}$

The Ayodhya dispute highlights both the attraction and potential for undue manipulation of material culture history where a clash of values is associated with strongly defended religious and nationalist traditions. This manipulation is also evident in the political context of archaeology in Israel where the excavation and interpretation of sites of Jewish historical or scriptural significance may be privileged over Moslem period sites and the values of Palestinian communities. ${ }^{45}$ In turn, Palestinian scholars have more recently begun excavating Ottoman period sites and 'are promoting a Canaanite past as evidence of their [preIsraelite] origins' ${ }^{46}$ However, sectional politics and politicians may also reference the more universal narratives of archaeology in situations of potential or real conflict. This seems to be consistent both with the reality of globalization and archaeology's achievement of subsuming local narratives of prehistory to 'universal comparative projects of western origin'. ${ }^{47}$ In new or postcolonial nations, the authority of the past may be invoked through revisionist narratives that usually follow standard disciplinary conventions, complete with radiocarbon chronologies and typologies celebrating great antiquity, the speed of evolutionary progress, or the relationship of the past to the modern polity. ${ }^{48}$ In the Caucasus, for example, 'the earliest evidence for domestication, for full-scale metallurgy, for monumental architecture' find their origins 'along the western shore of the Caspian (for an Azeri), in the lush foothills of the Great Caucasus and along the Black Sea coast (for a Georgian), or in the fertile Ararat valley of southern 
Transcaucasia (for an Armenian)'. ${ }^{49}$ It has been suggested that the 'recurrent, blatantly political interpretations of archaeological materials' in the Caucasus highlights the 'dangerously naïve postprocessual position' that any reading of the past 'is as valid and justifiable as another'. ${ }^{50}$

\section{Politics, IDENTITY AND the (IR)RELEVANCE of ARChaEOlogy}

The cases cited above highlight the potential impact of sectarian or politically correct archaeology on the interpretation of local heritage or sequences. There are other conflicts of interests and politics where the practice of archaeology may be allowed, but with a challenge to its disciplinary authority or independence. In China, archaeologists are motivated to convince Beijing authorities of the nationalist merit of particular regional traditions, including their contribution to the understanding of Chinese culture, to secure support. The interpretive strategy that results has been called the 'regionalist paradigm'. ${ }^{51}$ One does not need to indulge conspiracy theories to acknowledge that there are also establishment pressures of varying subtlety on research elsewhere, including the secular democracies of Europe, North America and Australasia. These may result from political, ethical and resource management concerns and conflicts, where archaeological knowledge production is negotiated with other cultural heritage interests and 'stakeholders'. ${ }^{52}$ As Rowlands observes, 'in the differing contexts of nationalism, development and the postmodern, we encounter the silences and gaps in archaeological explanations that determine which sites are excavated, what kinds of artifacts are privileged in the legitimizing of expert archaeological knowledges'. ${ }^{53}$ The consequent pressures of intellectual conformity on archaeologists seeking promotion or research grants are usually unstated, but well understood, in these situations.

There may be tension also in the operation of any national system of heritage management where local communities value their historical places for very different customary and cultural reasons than the State (or the majority). Here, western scientific conventions (including culture history classifications) and the non-authoritarian pluralism of interpretive archaeology may be equally at odds with the ways that local communities relate to their archaeological heritage. In these cases, the intervention or even the ideas of professional archaeology may be entirely unwelcome. This happens most frequently in the field of bioarchaeology, but it can occur in other heritage and identity contexts as well. Native American leader William Means is quoted as rejecting archaeological explanations of Indian origins with the affirmation: 'We do not need your [archaeological] past!'. Larry Zimmerman refers to other oral traditional Native American views that emphasize the spiritual unity of past and present so as to render archaeology's secular temporal narrative irrelevant, if not spiritually dangerous. ${ }^{54}$

In southern Africa the management value of heritage sites 'for their potential to inform about bygone days' can be contrasted with the views of indigenous African communities for whom these places 'are essentially links to the land, their 
ancestors, their cultures and traditions'. The importance of such places is as the continuing residence of ancestral spirits rather than their information values. ${ }^{55}$ The African archaeologists responsible for these observations note also that the archaeological knowledge and formal management of such places in southern Africa has become 'a preserve of the few', a non-traditional elite 'focused on the establishment of categories, typologies and chronology'. ${ }^{56}$ This clash of values is well illustrated by the vandalism of the 2000-10,000 year old archaeological rock shelter paintings at Domboshava, Zimbabwe. Customary rain-making ceremonies at a Domboshava rock shelter tunnel had been banned after the site was declared a national monument several decades ago. In the early 1980s part of a local 'sacred forest' was also cleared to make way for a museum and visitor facilities, while the ritual tunnel itself was sealed with cement. In this context, a significant area of the protected rock art was painted over in 1998, an act that was greeted with some sympathy by the local community. ${ }^{57}$

In many of the nations of Europe, North America and Australasia, archaeological regulation has allowed and even encouraged archaeological excavation to 'rescue' the information values of sites so as to 'mitigate' the destructive effects of development. Archaeologists have referred to this euphemistically as 'preservation by record'. Increasingly, however, local and indigenous communities such as New Zealand Maori have argued that their customary values are adversely affected by the regulated destruction and scientific priorities of archaeological management, where places with identified scientific values are approved for destruction on condition of prior investigation. ${ }^{58}$ For these communities, the practice of preservation by record is simply an official excuse to destroy their heritage, in which the participating archaeologists are viewed as collaborators. In Hawaii, for example, 'Hawaiian historians and cultural practitioners' identified a place affected by highway construction (the H3 corridor) as Kukuiokane Heiau, a temple site. Archaeologists interpreted the site as a dryland agricultural terrace only. ${ }^{59}$ The site's destruction was consequently approved by the state against appeals by the Hawaiian community, ${ }^{60}$ in the context of the expenditure of 17 million dollars on mitigation (including 'salvage') archaeology for the $\mathrm{H} 3$ highway. ${ }^{61}$

\section{Conclusion: CAN ARchaeology Resolve the PAst?}

The dilemma for contemporary archaeology is that while the discipline is becoming increasing self-critical and reflexive, ethnic and national identitybuilding patrons and end-users of archaeology are calling for, or proclaiming, greater certainty about the past. Indeed, as Rowlands has observed, 'the manipulation of archaeology in the shoring up of identities is now far more widespread than in the 1930s'. Furthermore, in spite of the advent of public archaeology, the information values of archaeological investigation may be of no interest, or be perceived as hostile to the concerns of contemporary communities.

Even where the authority of archaeology is superficially accepted by parties to a dispute, the Ayodhya conflict alone offers no assurance that it can resolve 
contemporary differences. Extensive subsurface excavations have not produced any definitive artifact or structure that proves - or disproves for that matter - the existence of Hindu temple foundations beneath the Masjid, at least as far as contending groups are concerned. Close inspection of the available evidence suggests that the stratigraphic and documentary records are characterized by cultural ambiguity. Instead of providing evidence of exclusive religious and cultural expressions, the material record at this site highlights considerable flexibility in the reuse of symbols and architectural remains, not least including the incorporation of columns of non-Muslim origins (whether Hindu, Buddhist or other) as visible, non-structural components of the Masjid itself. In part this represents the dissonance between the inflexible politics of prescriptive contemporary group identities, and the more fluid cultural boundaries of the historical record. This dissonance is an important factor in archaeology's seeming inability to resolve conflict in so many heritage contexts, as reported in this essay. However, the unique ability of archaeology to document unexpected historical and cultural inclusions suggests an important, if too infrequent, contribution of the material archaeological record in conflict situations. This contribution is not concerned with the political resolution of competing claims and authority. Instead, it is the challenge for contemporary communities in conflict to reflect on the archaeological evidence of acceptance and toleration as well as discord in their own cultural histories.

\section{ENDNOTES}

${ }^{1}$ There is as yet 'no agreed and undisputed term' for the public management of the physical (including archaeological) remains of the human past. F. P. McManamon and A. Hatton, 'Introduction: considering cultural management in modern society', in F. P. McManamon and A. Hatton (eds), Cultural Resource Management in Contemporary Society, One World Archaeology (OWA) 33, Routledge, London, 2000, p3, and discussion generally in Chapter 1, pp1-19. Among the available options (ibid), the broad term "cultura heritage' is used in this paper in deference to the cross-disciplinary nature of the seminar for which it was first prepared, and the publication in which it now appears.

${ }^{2}$ J. E. Tunbridge and G. J. Ashworth, Dissonant Heritage: The Management of the Past As a Resource in Conflict, John Wiley \& Sons, Chichester, England, 1996, pp20- 21

${ }^{3}$ Larry J. Zimmerman, 'We do not need your past! Politics, Indian time, and Plains archaeology', in Philip Duke and Michael C. Wilson (eds), Beyond Subsistence: Plains Archaeology and the Postprocessual Critique, The University of Alabama Press, Tuscaloosa, Alabama, 1995, pp28-45; M. de la Torre (ed), The Conservation of Archaeological Sites in the Mediterranean Region, The Getty Conservation Institute, LA, 1997; Robert Layton (ed), Conflict in the Archaeology of Living Traditions (OWA 8), Unwin Hyman, London, 1989; Robert Layton, Peter G. Stone \& Julian Thomas (eds), Destruction and Conservation of Cultural Property (OWA 41), Routledge, London, 2001.

${ }^{4}$ For example, see essays in Layton (ed), op cit, especially by Zimmerman (Chapters 4 and 16), in Layton et al (eds), op cit, especially with respect to Ayodhya and in Cressida Fforde, Jane Hubert and Paul Turnbull (eds), The Dead and their Possessions: Repatriation in Principle, Policy and Practice (OWA 43), Routledge, London, 2004 (2002), with respect to the repatriation of historic/prehistoric human remains. Some of these issues are discussed further in the body of this essay.

5 Jonathon D. Hill, 'Contested pasts and the practice of archaeology: Overview', in American Anthropologist, vol 94, no 4, 1992, pp809-15; Philip L. Kohl and Clare Fawcett (eds), Nationalism, Politics, and the Practice of Archaeology, Cambridge University Press, Cambridge, 1995; Layton (ed), op cit; Layton et al (eds), op cit.

${ }^{6}$ Summarised in Robert Layton and Julian Thomas, 'Introduction: the destruction and conservation of cultural property', in Layton et al (eds), op cit, pp6-11, and discussed further in text below.

${ }^{7}$ Barbara Bender, 'The politics of the past: Eiman Macha (Navan), Northern Ireland', in Layton et al (eds), op cit, pp199-211; Ann Hamlin, 'Archaeological heritage management in Northern Ireland: Challenges and solutions', in McManamon and Hatton (eds.), op cit, p68. 
${ }^{8}$ Barbara Bender, Stonehenge: Making Space, Berg, London, 1998.

${ }^{9}$ Bruce G. Trigger, A History of Archaeological Thought, Cambridge University Press, Cambridge, 1989, pp100; 114-19.

${ }^{10}$ ibid, pp110-47.

11 ibid, pp148-74; Bruce G. Trigger, 'Romanticism, nationalism and archaeology', in Kohl and Fawcett (eds), op cit, pp268-70.

${ }_{2}^{2}$ Philip L. Kohl and Clare Fawcett, 'Archaeology in the service of the state: theoretical considerations', in Kohl and Fawcett (eds.), op cit, p14.

${ }^{13}$ Bettina Arnold, 'The past as propaganda: totalitarian archaeology in Nazi Germany', in Antiquity, vol 64, no 244, 1990, pp464-78.

${ }^{14}$ Bettina Arnold and Henning Hassman, 'Archaeology in Nazi Germany: the legacy of the Faustian bargain', in Kohl and Fawcett (eds.), op cit, pp70-72; Ulrich Veit, 'Ethnic concepts in German prehistory: a cased study on the relationship between cultural identity and archaeological objectivity', in S. Shennan (ed), Archaeological Approaches to Archaeological Identity (OWA 10), Unwin Hyman, London, 1989, pp3556; Trigger, A History, op cit, pp163-67.

${ }^{15}$ Victor A. Shnirelman, 'From internationalism to nationalism: forgotten pages of Soviet archaeology in the 1930 s and 1940s', in Kohl and Fawcett (eds.), op cit, pp120-38; Trigger, A History, op cit, pp229-32.

${ }^{16}$ See, for example, V. Gordon Childe, The Dawn of European Civilization, London, Kegan Paul, 1925, The Aryans: A Study of Indo-European Origins, London, Kegan Paul, 1926 and Piecing Together the Past: The Interpretation of Archaeological Data, London, Routledge \& Kegan Paul, 1956.

${ }_{17}^{17}$ Arnold and Hassman, op cit, p71; Kohl and Fawcett, 'Archaeology in the service of the state', op cit, p14; Trigger, A History, pp167-74.

${ }^{18}$ Gordon R. Willey and Jeremy A. Sabloff, A History of American Archaeology, Third Edition, New York, W. H. Freeman, 1993 [1974].

${ }_{19}$ Lewis R. Binford, In Pursuit of the Past: Decoding the Archaeological Record, New York, Thames \& Hudson, 1983, p21. The classic statement of processual archaeology is Sally R. Binford and Lewis R. Binford (eds.), New Perspectives in Archaeology, Chicago, Aldine Press, 1968.

${ }^{20}$ Trigger, A History, op cit, pp312-16.

${ }^{21}$ ibid, p313.

${ }^{22}$ Ernestene L. Green (ed), Ethics and Values in Archaeology, New York, The Free press (Macmillan). 1984.

${ }^{23}$ For two influential articulations of this approach see lan Hodder, Reading the Past: Current Approaches to Interpretation in Archaeology, Cambridge, Cambridge University Press, 1986 and Michael Shanks and Christopher Tilley, Reconstructing Archaeology: Theory and Practice, Cambridge, Cambridge University

Press, 1987. The essays in Duke and Wilson (eds), op cit, provide a more recent application of interpretive archaeology approaches for the North American Plains.

${ }^{24}$ Zimmerman, 'We do not need your past', op cit; James F. Brooks, 'Sing away the Buffalo: Faction and fission on the Northern Plains', in Duke and Wilson (eds), op cit, pp143-68; see also relevant essays in Layton (ed), op cit.

${ }^{25}$ See, for example relevant essays in George C. Bond and Angela Gilliam (eds), Social Construction of the Past: Representation as Power, (OWA 24), Routledge, London, 1994; lan Hodder, Michael Shanks, Alexandra Alexandri, Victor Buchli, John Carman, Jonathan Last and Gavin Lucas (eds), Interpreting Archaeology: Finding Meaning in the Past, Routledge, London, 1995 and Duke and Wilson (eds), op cit. ${ }^{26}$ Philip L. Kohl and Clare Fawcett, 'Archaeology in the service of the state', in Kohl and Fawcett (eds), op cit, p8.

${ }_{27}^{27}$ Bruce Trigger, 'Romanticism, nationalism, and archaeology', in Kohl and Fawcett (eds), op cit, pp263, 264.

${ }_{29}^{28}$ Layton and Thomas, 'Introduction', op cit, pp16-17 (quotes on p17).

${ }^{29}$ ibid, p19.

${ }^{30}$ Neil Asher Silberman, 'Promised lands and chosen peoples: the politics and poetics of archaeological narrative', in Kohl and Fawcett (eds), op cit, p258.

${ }^{31}$ See Sarvepallia Gopal, Anatomy of a Confrontation: Ayodhya and the Rise of Communal Politics in India, Zed Books, London, 1993; Layton and Thomas op cit, pp2-11, Nandini Rao, 'Interpreting silences: symbol and history in the case of the Ram Janmabhoomi/Babri Masjid', in Bond and Gilliam (eds), op cit, pp154-64; Nandini Rao and C. Rammanohar Reddy, 'Ayodhya, the print media and communalism', in Layton et al (eds), pp139-56 and Shereen Ratnagar [et al. for comments], 'Archaeology at the Heart of a Political Confrontation: The Case of Ayodhya', in Current Anthropology, vol 45, no 2, 2004, pp239-59.

${ }^{32}$ Layton and Thomas, op cit, pp3-6.

${ }^{33}$ B. B. Lal, 'A note on the excavations at Ayodhya with reference to the Mandir-Masjid issue', in Layton et al (eds), pp117-20.

34 ibid, pp119-23.

35 ibid, p119. Lal's work at Ayodhya and other sites associated with the Hindu epics was reported internationally in his paper 'The two Indian epics vis-à-vis archaeology' in Antiquity vol 55, no 213, 1981 , pp27-34. While this report assumes the historical association of Ayodhya in Uttar Pradesh with the Ramayana site, it is focused on the Northern Black Polished Ware culture period (pp30-32). There is no discussion of the construction of a temple to Rama or the Masjid itself (see also Layton and Thomas, op cit, p3).

${ }^{36}$ Lal, 'A Note', op cit, pp121-24. 
${ }^{37}$ R. Sharan Sharma, 'The Ayodhya issue,' in Layton et al (eds), op cit, pp127-38.

${ }^{38}$ ibid, pp132-34.

${ }^{39}$ ibid, pp130-32.

${ }^{40}$ Lal, op cit, pp124-26; Sharma, op cit, pp134-37.

${ }^{41}$ Lal, op cit, pp124-25.

42 Sharma, op cit, pp136-37.

${ }^{43}$ As reviewed by Nayanjot Lahiri, 'Ayodhya - Not a treasure hunt', in World Archaeological Bulletin, vol 18, August-September 2003, pp73-78.

${ }^{44}$ ibid, p78.

${ }^{45}$ Ann E. Killebrew, 'The presentation of archaeological sites in Israel', in Conservation and Management of Archaeological Sites, vol 3, nos 1 and 2, 1999, pp17-32.

${ }^{46}$ ibid, p30.

${ }^{47}$ Michael Rowlands, 'The politics of identity in archaeology', in Shennan (ed), op cit, p138.

${ }^{48}$ Silberman, op cit, p257.

${ }^{49}$ Philip L. Kohl and Gocha R. Tsetskhadze, 'Nationalism, politics, and the practice of archaeology in the Caucasus', in Kohl and Fawcett (eds), op cit, p168.

${ }^{50}$ ibid, pp168-69.

${ }^{51}$ Lothar von Falkenhausen, 'The regionalist paradigm in Chinese archaeology', in Kohl and Fawcett (eds), op cit, pp198-217.

${ }^{52}$ Rosemary A. Joyce, 'Academic freedom, stewardship and cultural heritage: weighing the interests of stakeholders in crafting repatriation approaches', in Fforde, Hubert and Turnbull (eds), op cit, pp. 99-107. ${ }^{53}$ Rowlands, op cit, p141.

${ }^{54}$ Zimmerman, 'We do not need your past!', op cit.

${ }^{55}$ Webber Ndoro and Gilbert Pwiti, 'Heritage management in southern Africa: Local, national and international discourse', in Public Archaeology, vol 2, no 1, 2001, p33.

${ }_{57}^{56}$ Ndoro and Pwiti, op cit, p23.

${ }^{57}$ Pascal Taruvinga and Webber Ndoro, 'The vandalism of the Domboshava rock painting site, Zimbabwe', in Conservation and Management of Archaeological Sites, vol 6, no 1, 2003, pp3-10.

${ }^{58}$ Harry Allen, Protecting Historic Places in New Zealand, Research in Anthropology and Linguistics, no 1 , Department of Anthropology, University of Auckland, 1998, pp35; 37-41.

${ }_{59}$ C. Kehaunani Cachola-Abad and Edward Halealoha Ayau, 'He Pane Ho'omalamalama: Setting the record straight and a second call for partnership', in Hawaiian Archaeology, vol 7, 1999, p76.

${ }^{60}$ ibid.

${ }^{61}$ Patrick Kirch, 'Hawaiian archaeology: Past, present and future', in Hawaiian Archaeology, vol 7, 1999, pp67-68. 